\title{
METODY LECZENIA BÓLU NEUROPATYCZNEGO W OPIECE PALIATYWNEJ. OPIS PRZYPADKÓW
}

\section{METHODS OF NEUROPATHIC PAIN TREATMENT IN PALLIATIVE CARE PATIENTS - CASE STUDY}

\author{
Lucyna Iwanow ${ }^{1,2}$, Karolina Włostowska ${ }^{3}$, Mariusz Panczyk ${ }^{4}$, Joanna Gotlib ${ }^{4}$ \\ ${ }^{1}$ Studenckie Koło Naukowe Prawa Medycznego \\ Warszawski Uniwersytet Medyczny \\ ${ }^{2}$ Studenckie Koło Naukowe Medycyny Paliatywnej \\ Warszawski Uniwersytet Medyczny \\ ${ }^{3}$ Zakład Pielęgniarstwa Klinicznego \\ Warszawski Uniwersytet Medyczny \\ ${ }^{4}$ Zakład Dydaktyki i Efektów Kształcenia \\ Warszawski Uniwersytet Medyczny
}

DOI: https://doi.org/10.20883/pielpol.2017.48

\section{STRESZCZENIE}

Ból pełni rolę ochronną w organizmie ludzkim, ostrzegając przed zagrożeniem w postaci urazu czy choroby. Można go podzielić pod względem miejsca powstania na ból receptorowy oraz niereceptorowy, zwany inaczej patologicznym. Najczęstszym bólem patologicznym jest ból neuropatyczny. Ból neuropatyczny obejmuje wiele zespołów bólowych o różnej etiologii i umiejscowieniu. Jest on nieodłączną konsekwencją uszkodzenia nerwu w wyniku urazu, ucisku czy choroby.

W pracy przeanalizowano dokumentację medyczną dziewięciu pacjentów objętych opieką hospicyjną z bólem neuropatycznym w przebiegu choroby nowotworowej.

SŁOWA KLUCZOWE: ból neuropatyczny, opieka paliatywna, opieka hospicyjna, metody leczenia bólu.

\section{Wstęp}

Zagadnienie bólu neuropatycznego jest ciągle w fazie badań klinicznych. Znana jest większość przyczyn występowania tego bólu, jednak w dalszym ciągu nie opracowano skutecznych metod jego leczenia. Wiele środków farmaceutycznych, które przynoszą ulgę w bólu, w przypadku bólu neuropatycznego nie wykazuje skuteczności. Obecnie na świecie prowadzonych jest wiele badań zarówno na zwierzętach, jak i w grupach osób z różnymi dolegliwościami neuropatycznymi. Niektóre grupy leków mają udowodnioną większą skuteczność w leczeniu bólu neuropatycznego niż inne, często łatwo dostępne na rynku farmaceutycznym [1].

Wyzwaniem dla medycyny XXI wieku są pacjenci poddani opiece paliatywnej, u których wystąpił ból neuropatyczny przy istniejących już chorobach. Grupa ta charakteryzuje się nieuleczalnością swoich chorób.

\begin{abstract}
Pain is an unpleasant emotional and physical sensation that has a protective function in the body, warning about dangers such as an injury or disease. Pain may be divided with reference to the site of occurrence into nociceptive and neuropathic (also called pathological). Neuropathic pain is the most common kind of pathological pain. Neuropathic pain comprises a number of pain syndromes of different aetiology and locations. It is an inherent consequence of nerve damage due to an injury, compression, or disease.

The study presented the medical documentation of nine patients undergoing hospice care with neuropathic pain in cancer.
\end{abstract}

KEYWORDS: neuropathic pain, palliative care, pain treatment.

Osoby te nie poddają się już leczeniu przyczynowemu. Głównym celem opieki paliatywnej jest poprawa jakości życia chorego, uśmierzanie bólu oraz godne umieranie [2].

Celem pracy jest analiza historii chorób pacjentów przebywających w hospicjum stacjonarnym z wielochorobowością, u których rozpoznano m.in. ból neuropatyczny.

\section{Opisy przypadków}

\section{Przypadek 1}

\section{Kobieta, 67 lat}

Rozpoznanie: rak pęcherzyka żółciowego (stan po operacji i chemioterapii z marca 2010 r.)

Choroby towarzyszące: astma oskrzelowa, nadciśnienie tętnicze, przewlekła choroba nerek, choroba zwyrodnieniowa kręgosłupa, osteoporoza, stan po 
dwóch udarach niedokrwiennych mózgu, padaczka objawowa, rozwarstwienie dystalnego odcinka tętnicy szyjnej wewnętrznej prawej, zaćma, jaskra

Uczulenie: sulfonamidy i salicylany

Data przyjęcia do hospicjum stacjonarnego: 02.04.2014 r.

Historia choroby w kontekście objawów bólowych

Pacjentka przyjęta z bólem w prawym nadbrzuszu i śródbrzuszu. Początkowo leczona środkami: Lyrica 75 mg $2 \times 1$ tabl., Cital 20 mg $1 \times 1$ tabl., MST $100-60$ - 100 mg, OxyContin 120-40-120 mg, Morphini Sulfas s.c. $40 \mathrm{mg}$ co $4 \mathrm{~h}$ oraz Matrifen $200 \mu \mathrm{g} / \mathrm{h} / 72 \mathrm{~h}$. Stopniowo obniżano dawkę MST. Ostatecznie uzyskano 2 x 60 mg. Zmniejszano też dawki Morphini Sulfas do $15 \mathrm{mg}$ co 4 h. Dwa razy próbowano odstawić Lirycę, jednak ostatecznie chora przyjmowała ją w dawce 2 x $150 \mathrm{mg}$.

Natężenie bólu oznaczane w zbiorczej uproszczonej ocenie stanu chorego i efektywności opieki było zmienne, określane na 1 lub 2 skali VAS.

Pojawił się ból w prawym podżebrzu oceniany wg skali VAS na 1-2. W ciągu kilku dni w tej samej skali osiągnął on już próg 7 z towarzyszącym promieniowaniem do pleców. Chora zgłaszała ból przy chodzeniu, w skali VAS oceniła go na 1-3.

Z chwilą wypisu do domu chora przyjmowała: Cital $20 \mathrm{mg}$, Matrifen $100 \mu \mathrm{g} / \mathrm{h} / 72 \mathrm{~h}$, Morphini Sulfas $15 \mathrm{mg}$ co 4 h, MST 2 x 60 mg oraz Lyrica 2 x 150 mg (w godzinach 8:00, 20:00).

\section{Przypadek 2}

Mężczyzna, 69 lat

Rozpoznanie: mięsak pleomorficzny miednicy mniejszej, rak prostaty

Choroby towarzyszące: luty 2014 r. zawał NSTEMI - stent BMS, napady migotania przedsionków, nadciśnienie tętnicze

Data przyjęcia do hospicjum stacjonarnego: 14.03.2014

Historia choroby w kontekście objawów bólowych

Pacjent przyjęty z bólem kości uniemożliwiającym mu sen w nocy. Uskarżał się na ból biodra prawego nasilający się przy poruszaniu. Początkowo był leczony: Matrifen $75 \mu \mathrm{g} / \mathrm{h} / 24 \mathrm{~h}$, Neurontin 2 x $100 \mathrm{mg}$ oraz Effentora $200 \mu g 2$ x 1 tabl. w razie potrzeby. Z czasem został dołączony Ketonal w dawce 100 mg i.v. oraz Perfalgan $1 \mathrm{~g}$ w razie potrzeby. Po tygodniu od przyjęcia pacjent zgłaszał zmniejszenie dolegliwości bólowych. Dodano do farmakoterapii Instanyl w dawce $100 \mu \mathrm{g}$ w razie potrzeby. Po miesiącu od przyjęcia zwiększono dawkę Instanylu do $200 \mu \mathrm{g}$ w razie potrzeby, odstawiono również Neurontin. Dzień po odstawieniu Instanylu $200 \mu \mathrm{g}$ w razie potrzeby dodano do leczenia Neurontin 3 x 300 mg oraz zwiększono dawkę Matrifenu do $100 \mu \mathrm{g} / \mathrm{h} / 72 \mathrm{~h}$. W maju pacjen- towi dodano Morphini Sulfas s.c. $6 \times 1 \mathrm{mg}$ plus w razie potrzeby. Pacjent nadal zgłaszał bóle biodra oraz przy poruszaniu się. W momencie analizy historii choroby pacjent przyjmował: Perfalgan $1 \mathrm{~g}$ w razie potrzeby, Perfalgan $1 \mathrm{~g}$ (o godzinie 16:00), Pyralgin $5 \mathrm{ml}$ w razie potrzeby, Matrifen $100 \mu \mathrm{g} / \mathrm{h} / 72 \mathrm{~h}$, Neurontin 300-300-600 mg oraz Morphini Sulfas s.c. $6 \times 1 \mathrm{mg}$ plus w razie potrzeby.

W zbiorczej uproszczonej ocenie stanu chorego i efektywności opieki ból biodra wahał się od 1 do 3 w skali VAS. U pacjenta nie zastosowano innych skal oceny bólu.

\section{Przypadek 3}

\section{Mężczyzna, 38 lat}

Rozpoznanie: rak odbytu z przerzutem do płuc, kości, węzłów chłonnych, lewej półkuli mózgu, szpiku kostnego

Choroby towarzyszące: padaczka, stan po stabilizacji kręgosłupa, nadczynność tarczycy, niedowład prawej kończyny górnej, stan po lewostronnym zapaleniu płuc (luty 2014 r.)

Data przyjęcia do hospicjum stacjonarnego: 24.03.2014

Historia choroby w kontekście objawów bólowych

Pacjent przyjęty z bólem kręgosłupa, miednicy i lewego uda. Początkowo przyjmował: Morphini Sulfas w pompie 2 mg/h/24h, Pyralgin 5 ml 3 x 1 amp. i.v., Neurontin $100 \mathrm{mg} 3 \times 1$ tabl., Tegretol CR $200 \mathrm{mg} 3 \times 1$ tabl. Chory ciągle uskarżał się na silne bóle w okolicy biodra lewego oraz miednicy. Bóle nasilały się przy poruszaniu, miały charakter przeszywający. Według zbiorczej uproszczonej oceny stanu chorego i efektywności opieki ból utrzymywał się na poziomie 2 w trzystopniowej skali. Pacjentowi stopniowo zwiększano dawki morfiny w pompie oraz w bolusie. Zwiększono również dawki Neurontinu 300-100-300 mg oraz dołączono do terapii Instanyl $100 \mu \mathrm{g}$ do podawania w razie potrzeby. Pacjent w skali VAS ból oceniał na 3 w spoczynku i na 7 podczas poruszania się. Obniżono dawkę Tegretolu CR do $2 \times 200$ mg oraz zwiększono Morphini Sulfas do $5 \mathrm{mg} / \mathrm{h} / 24 \mathrm{~h}$ w pompie i $3 \mathrm{mg}$ w bolusie. Przy podaniu Instanylu w dawce $200 \mu \mathrm{g}$ oraz Morphini Sulfas w pompie $6 \mathrm{mg} / \mathrm{h} / 24 \mathrm{~h}$ oraz w bolusie $3 \mathrm{mg}$ udało się opanować dolegliwości bólowe. Po kilku dniach bóle powróciły. Zwiększono dawkę Morphini Sulfas do $8 \mathrm{mg} / \mathrm{h} / 24 \mathrm{~h}$ w pompie oraz $4 \mathrm{mg}$ w bolusie. Dołączono Ketonal $100 \mathrm{mg}$ oraz Pyralginę $5 \mathrm{ml}$ i.v. podawane na w razie potrzeby.

Obecnie dolegliwości bólowe zostały opanowane, a pacjent przyjmuje: Pyralgin $5 \mathrm{ml} 3 \times 1$ amp. i.v., Neurontin p.o. 300-100-300mg, Tegretol CR p.o. $2 \times 100 \mathrm{mg}$, Instanyl $200 \mu \mathrm{g}$, Morphini Sulfas (i.v-pompa) $8 \mathrm{mg} /$ h/24h oraz 4 mg bolus, Ketonal 100 mg oraz Pyralginę $5 \mathrm{ml}$ i.v. podawane na w razie potrzeby. 


\section{Przypadek 4}

Kobieta, 86 lat

Rozpoznanie: rak sutka prawego, stan po mastektomii prawostronnej (18 lat temu zabieg oszczędzający, 8 lat temu mastektomia)

Choroby towarzyszące: złamanie patologiczne kości udowej prawej - odmowa leczenia operacyjnego, stan po usunięciu przerzutu raka gruczołowego piersi do skóry przedramienia prawego

Data przyjęcia do hospicjum stacjonarnego: 26.03.2013

Historia choroby w kontekście objawów bólowych

Chora przyjęta z silnymi bólami prawego biodra. Początkowo przyjmowała Morphini Sulfas s.c. $6 \times 1$ mg plus $1 \mathrm{mg} \mathrm{w}$ razie potrzeby, następnie zwiększono dawkę w razie potrzeby do $2 \mathrm{mg}$. Ból nogi pacjentka oceniała na 3 wg zbiorczej uproszczonej oceny stanu chorego i efektywności opieki. Po dwóch tygodniach pojawiły się bóle brzucha oraz całej nogi. Dołączono Pyralginę $2 \mathrm{ml}$ i.v. w razie potrzeby. Z czasem dolegliwości bólowe nasiliły się. Zwiększono dawkę Morphini Sulfas s.c. do $6 \times 2$ mg, kontynuowano podawanie Pyralginy $2 \mathrm{ml}$ dołączono również Paracetamol $1 \mathrm{~g} \mathrm{w}$ razie potrzeby. Po pół roku od przebywania w hospicjum dołączono Ketonal 100 mg p.o. w razie potrzeby. Bóle stale się nasilały. Włączono do farmakoterapii Gabapentynę p.o. w dawce 3 x 100 mg, po kilku dniach zmieniono dawkowanie na 100-100-300 mg. Ból nogi zmniejszył się i był oceniany wg zbiorczej oceny na 1 . Zmniejszono dawkę Gabapentyny do 0-0-100 mg, dodano MST w dawce $2 \times 30 \mathrm{mg}$.

Obecnie pacjentka jest leczona: Sevredol $10 \mathrm{mg}$ w razie potrzeby, MST 2 x 30 mg, Gabapentyna 0-0-100 mg.

\section{Przypadek 5}

Kobieta, 86 lat

Rozpoznanie: nowotwór złośliwy odbytnicy

Data przyjęcia do hospicjum domowego: 27.01.2011

Historia choroby w kontekście objawów bólowych

Udostępniono wgląd do dokumentacji medycznej pacjentki od dnia 4.01.2014. Pacjentka wówczas uskarżała się na bóle kostne oceniane w skali VAS na 7-8. Przyjmowała: Durogesic $25 \mu \mathrm{g}$ co $72 \mathrm{~h}$. w plastrach, Tramal 100 mg p.o. oraz Diclofenac 40 mg w razie potrzeby.

Wizyty lekarskie odbywały się w odstępach 7-10 dni. Ból stale się utrzymywał, oceniany był w skali VAS na 6-8. W lutym ból nadal pozostawał na poziomie 8 w skali VAS i miał charakter neuropatyczny. Udało się opanować dolegliwości bólowe, jednak po 10 dniach od stabilizacji ponownie pojawiły się bóle kostne oceniane w skali VAS na 5-6. Dołączono na stałe do terapii przeciwbólowej Ketonal w dawce 2 × 50 mg.

Pacjentka nadal uskarża się na bóle kostne. Podczas analizy historii choroby chora była leczona farmakologicznie: Tramal 100 mg p.o., Diclofenac 40 mg w razie potrzeby oraz Ketonal w dawce 2 × 50 mg.

\section{Przypadek 6}

\section{Kobieta, 80 lat}

Rozpoznanie: nowotwór złośliwy bez konkretnego umiejscowienia

Data przyjęcia do hospicjum domowego: 01.10.2013

Historia choroby w kontekście objawów bólowych

Udostępniono wgląd do dokumentacji medycznej od dnia 7.01.2014. Chora zgłasza sporadyczny ból opasujący o charakterze neuralgii, utrudniający zaczerpnięcie oddechu. Wizyty domowe lekarza odbywały się systematycznie w odstępach 7-10-dniowych. Początkowo pacjentka była leczona: Matrifen $12 \mu \mathrm{g} / \mathrm{h}$ oraz MST 2 × $30 \mathrm{mg}$.

Po dwóch tygodniach nastąpiło zmniejszenie dolegliwości bólowych. Przy następnej wizycie po siedmiu dniach chora ponownie zgłaszała nasilenie objawów bólowych. Zwiększono dawkę Matrifenu do $25 \mu \mathrm{g} / \mathrm{h}$ co 72 h. Dolegliwości bólowe uległy zmniejszeniu aż do połowy marca, gdy ponownie zostały zgłoszone okresowe bóle opasujące, silniejsze po stronie lewej.

Pacjentka stale jest leczona przeciwbólowo Matrifenem $25 \mu \mathrm{g} / \mathrm{h}$ co $72 \mathrm{~h}$ oraz MST 2 × $30 \mathrm{mg}$.

\section{Przypadek 7}

\section{Kobieta, 76 lat}

Rozpoznanie: nowotwór złośliwy bez konkretnego umiejscowienia

Data przyjęcia do hospicjum domowego: 15.03.2013

Historia choroby w kontekście objawów bólowych Udostępniono historię choroby od dnia 2.01.2014. Pacjentka zgłaszała ból głowy oraz kręgosłupa w odcinku szyjnym. W skali VAS oceniła go na 1-2. Początkowo była leczona: Paracetamol 1g oraz OxyContin 2 x $10 \mathrm{mg}$.

Po tygodniu dołączono do terapii przeciwbólowej Matrifen w dawce $75 \mu \mathrm{g} / \mathrm{h}$ co 72 h. W lutym nastąpiło zmniejszenie dolegliwości bólowych (VAS 1-2). Zmniejszono OxyContin do $2 \times 5 \mathrm{mg}$. W połowie miesiąca chora zgłosiła ból lewego biodra. Zwiększono dawkę OxyContinu do 2 x $25 \mathrm{mg}$. Ponownie nastąpiło zniesienie bólu. W połowie marca do bólów kostnych ocenianych w skali VAS na 1-2 dołączył ból przy poruszaniu się, oceniany w skali VAS na 3-4. Pod koniec miesiąca bóle zostały opanowane (VAS 1-2).

Obecnie pacjentka przyjmuje: Paracetamol $1 \mathrm{~g}$, OxyContin 2 x 25 mg oraz Matrifen $75 \mu \mathrm{g} / \mathrm{h}$ co 72 h. 


\section{Przypadek 8}

\section{Kobieta, 67 lat}

Rozpoznanie: rak pęcherzyka żółciowego (po leczeniu operacyjnym i chemioterapii)

Data przyjęcia do hospicjum domowego: 24.06.2013

Historia choroby w kontekście objawów bólowych

Pacjentka obecnie przebywa pod opieką domową, jednakże zdarzają się incydenty przyjęcia do hospicjum stacjonarnego w celu unormowania stanu zdrowia, po czym ponownie wraca pod opiekę domową. Udostępniona historia choroby od stycznia $2014 \mathrm{r}$.

Pacjentka zgłaszała dolegliwości bólowe średniego natężenia. Po pięciu dniach pojawił się przeszywający, przebijający ból po prawej stronie brzucha, oceniany w skali VAS na 7-8. Pacjentka przyjmowała: Matrifen $75 \mu \mathrm{g} / \mathrm{h}$ co 72 h, MST 2 x 60 mg, Instanyl $200 \mu \mathrm{g}$ do 8 razy na dobę oraz OxyContin p.o. 2 x 40 mg. Dolegliwości bólowe zostały opanowane. Po czterech dniach pojawił się silny ból w prawym podżebrzu, oceniany w skali VAS na 10. Zwiększono dawkę Matrifenu do $100 \mu \mathrm{g} / \mathrm{h}$ co $72 \mathrm{~h}$, OxyContinu do 2 x 80 mg, dołączono też Effentorę 200 mg w przypadku wystąpienia bólu przebijających. Stale utrzymywał się silny ból po prawej stronie brzucha, dodatkowo występowały bóle o charakterze trzewnym, kostnym, neuropatycznym, przebijające trwające 30-40 min. oceniane w skali VAS na 8-9. Ruch wzmagał dolegliwości bólowe, dodatkowo ból uniemożliwiał sen. Do przyjmowanych leków dołączono Diclofenac 75 mg, Instanyl $200 \mu \mathrm{g}$ do 8 razy na dobę oraz Morphinum Sulfas s.c. $20 \mathrm{mg}$ co 4-6h. Dolegliwości bólowe utrzymywały się, a nawet wzmagały w nocy. Dołączono DicloDuo w dawce 1 x 75 mg. Pod koniec stycznia pacjentka oceniała ból w skali VAS na 10. Zwiększono dawkę MST do 2 × $90 \mathrm{mg}$. Ból stale narastał, ponownie przybrał charakter przeszywający, trzewny, neuropatyczny. Pacjentka przyjmowała: Matrifen $150 \mu \mathrm{g} / \mathrm{h}$ co 72 h, Morphini Sulfas s.c. 30-40 mg co 4h, MST 2 x 90 mg, Neurontin 2 x $100 \mathrm{mg}$. Dolegliwości bólowe udało się opanować po czterech dniach. Następnego dnia pacjentka ponownie zgłaszała silne dolegliwości bólowe w obrębie brzucha, VAS 8-10. Mimo wielokrotnej modyfikacji dawek leków nie udało się opanować dolegliwości bólowych. Ból stale utrzymuje się w skali VAS 7-9.

W momencie analizy historii choroby pacjentka przyjmowała: Morphini Sulfas 20-40 mg co 4 h, Instanyl w dawkach 50, 100, $200 \mu \mathrm{g}$ każdy do 8 razy na dobę, OxyContin 2 x $80 \mathrm{mg}$.

\section{Przypadek 9}

Kobieta, 76 lat

Rozpoznanie: nowotwór złośliwy trzustki

Data przyjęcia do hospicjum domowego: 01.10.2012

Historia choroby w kontekście objawów bólowych
Pacjentka przebywała pod opieką zarówno hospicjum domowego, jak i stacjonarnego. W chwili analizy historii choroby przebywała pod opieką domową, dostępna historia choroby od dnia 02.01.2014

Chora zgłaszała narastające bóle trzewne, oceniane w skali VAS na 4-5. Przyjmowała: OxyContin 2 x 40 mg oraz Neurontin $3 \times 100 \mathrm{mg}$. Po dwóch tygodniach dolegliwości bólowe nie ustąpiły, dołączył się natomiast charakter trzewny i neuropatyczny, z czasem wystąpiły również bóle i drętwienia kończyn dolnych. VAS cały czas utrzymywał się na poziomie 3-5. Zwiększono przyjmowanie dawki Neurontinu do $2 \times 2$ tabl. $100 \mathrm{mg}$. Po dwóch miesiącach ból nie zmieniał się. Zwiększono dawkę Neurontinu do 200 mg 2x2 tabl.

Ostatni wpis w historii choroby zawierał ból oceniany w skali VAS na 4. Pacjentka przyjmuje: OxyContin 2 x 40 mg oraz Neurontin 200 mg 2 x 2 tabl.

\section{Dyskusja}

Analiza aktualnego piśmiennictwa światowego ukazała niewystarczająca liczbę badań oraz niewystarczający poziom wiedzy na temat leczenia bólu neuropatycznego. Mimo, że prezentowane w literaturze światowej badania wykazały skuteczność leków z grup TCA oraz SSRI, obecnie ból neuropatyczny nadal jest leczony przy pomocy opioidów oraz NLPZ [3-5].

Prezentowane w pracy przypadki pacjentów, u których leczono ból neuropatyczny, są specyficzne ze względu na fakt, że byli to pacjenci leczeni paliatywnie. W tej opisywanej pacjentów wystąpiły charakterystyczne opisy bólu neuropatycznego. Pacjenci opisywali ból jako opasujący, utrudniający oddychanie, przeszywający, przebijający, kłujący, piekący, zgniatający, tępy, ściągający, świdrujący, palący, promieniujący. Wystąpiła też allodynia termiczna oraz czuciowa, niedoczulica obwodowa i drętwienia. W większości przypadków ból nasilał się przy poruszaniu bądź zmianie pozycji, utrudniał sen, budząc tym samym niepokój [1]. Trudność w ocenie bólu, jego wiarygodne odczucie fizyczne często przysłonięte odczuciem psychicznym oraz ogólnym stanem, problem wielolekowości, wielochorobowością, stanu wyniszczenia organizmu charakterystycznego dla pacjenta w opiece paliatywnej często skutkował problemem z opanowaniem bólu, pomocą pacjentowi w uzyskaniu homeostazy i możliwości bezbolesnego funkcjonowania w tych ostatnich chwilach życia [4].

W ukazanych przypadkach stosowane było leczenie środkami przeciwbólowymi, opioidami, lekami przeciwdepresyjnymi, przeciwdrgawkowymi. Z grupy leków przeciwbólowych stosowane były Matrifen, Effentora, Ketonal, Perfalgan, Pyralgin, Instanyl, Paracetamol, Tramal, Diclofencac oraz DicloDuo. Z grupy opioidów podawane były: OxyContin, Morphini Sulfas, Sevredol 
oraz Durogesic. Stosowano również leki przeciwdrgawkowe i przeciwpadaczkowe, takie jak Lyrica, Neurontin, Tegretol, Gabapentyna. Podawany był również Cital, który jest lekiem przeciwdepresyjnym.

Opisane przypadki ukazały trudność w odpowiednim doborze dawek leków w celu odpowiedniego leczenia przeciwbólowego. Sporadycznie występowała próba nazwania, rozpoznania dolegliwości bólowej. Niejednokrotnie mimo utrzymujących się dolegliwości modyfikowano leczenia przeciwbólowego.

Ciekawy jest fakt, że pacjenci objęci opieką domową mieli dużo większe dolegliwości bólowe niż pacjenci objęci opieką hospicyjną. Warto zastanowić się, czy jest to wynik przypadkowy czy spowodowany zbyt długimi odstępami czasu między wizytami personelu medycznego w domach pacjentów. W celu dokładnej analizy tego zagadnienia zaleca się powtórzenie badania na większej grupie pacjentów.

W analizowanym materiale wystąpiła skala oceny bólu VAS. W sposób przejrzysty ukazała modyfikację natężenia bólu. Bez tej skali miarodajna ocena bólu byłaby niemożliwa, a co za tym idzie niemożliwe byłoby odpowiednie dobranie dawki leku do potrzeb pacjenta bądź mogłoby wystąpić ryzyko przedawkowania leków.

W wielu opisanych przypadkach nie było wyjściowej oceny natężenia bólu przed modyfikacją leczenia przeciwbólowego. Prowadzona ocena zmian natężenia bólu nie była prowadzona systematycznie, przez to niemożliwe było monitorowanie zmian natężenia oraz reakcji organizmu pacjentów na zastosowane leczenie [6].

Coraz częściej mówi się, że ból jest piątym parametrem życiowym. Obecna medycyna kładzie duży nacisk na uśmierzanie bólu. Larysz, Czapla i Copik wskazują, że nieodpowiednie leczenie przeciwbólowe przekłada się na nieprawidłową rehabilitację, opóźnienie gojenia ran, spadek odporności, wzrost ciśnienia tętniczego krwi, niekorzystny wpływ na psychikę chorego, ale też na wzrost kosztów leczenia pacjenta [7]. Wspomniane autorki wymieniają również błędy w leczeniu przeciwbólowym. Wskazują na nieumiejętność doboru schematu leczenia przeciwbólowego, podawanie leków na żądanie pacjenta a nie z wyprzedzeniem, określanie dawek leków na „oko” a nie na podstawie wagi pacjenta, niechęć personelu do stosowania leków opioidowych oraz złą drogę podania leku, która wpływa na czas wchłaniania [7].

Wykwalifikowany personel pielęgniarski powinien być zdolny do działania w taki sposób, aby lek był podany w odpowiednim czasie, w odpowiedniej dawce oraz odpowiednią drogą. Niezbędna jest również kontrola podstawowych parametrów życiowych, których odchylenia mogą wskazywać na nasilenie się dolegliwości bólowych. Małgorzata Juda w swojej publikacji twierdzi, że pielęgniarka jest tą osobą w systemie zdrowia, która spędza najwięcej czasu z pacjentem, a co za tym idzie powinna być odpowiednio wyedukowana w zakresie zwalczania bólu [8].

\section{Piśmiennictwo}

1. O’Connor A, Dworkin RH. Ból neuropatyczny. Med Dypl 2009; 1 (2): 13-17

2. Millan MJ. The induction of pain: an integrative review. Prog Neurobiol 1999; 57 (1): 164-169.

3. Lotsch J, Skarke C, Tegeder I. i wsp. Drug interactions with patient-controlled analgesia. Clin. Pharmacokient 2002; 41: 31-37.

4. Eriksen J, Sjogren P, Bruera E. i wsp. Critical issues on opioid in chronic non-cancer pain: an epidemiological study. Pain 2006; 125: 172-179.

5. Goldsein FJ. Anjuncts to opioid therapy. JAOA 2002; 102: S15-S21.

6. Santiago-Figueroa J, DP. Kuffler DP. Reducing and eliminating neuropathic pain. P.R. Health Sci. J 2009; 28: 289-300.

7. Larysz A, Czapla K, Copik I. Nowoczesna terapia bólowa. Ból jako piąty parameter życiowy; Mag Piel Położ 2013; 6; 40-41.

8. Juda M. Rola pielęgniarki w zwalczaniu bólu pooperacyjnego; Piel Pol 2005; 3(57); 333-336.

Artykuł przyjęty do redakcji: 10.05.2016

Artykuł przyjęty do publikacji: 11.07.2016

Źródło finansowania: Praca nie jest finansowana z żadnego źródła. Konflikt interesów: Autorzy deklarują brak konfliktu interesów.
Adres do korespondencji:
Joanna Gotlib
ul. Żwirki i Wigury 61
02-091 Warszawa
tel.: 225720 490, fax: 225720491
e-mail: joanna.gotlib@wum.edu.pl
Zakład Dydaktyki i Efektów Kształcenia
Warszawski Uniwersytet Medyczny 